\title{
Pengaruh Penggunaan Gadget dan Peran Orang Tua Terhadap Hasil Belajar Mahasiswa di Masa Covid-19
}

\author{
Stefania Baptis Seto ${ }^{1}$, Maria Trisna Sero Wondo ${ }^{2}$, Maria Fatima $\mathrm{Mei}^{3}$ \\ 1, 2, 3 Program Studi Pendidikan Matematika, Fakultas Keguruan dan Ilmu Pendidikan, Universitas Flores, \\ Jl. Sam Ratulangi, Ende-Flores-NTT, Indonesia \\ stefaniseto@gmail.com
}

\begin{abstract}
The purpose of this study was to determine the influence of the use of gadgets and the role of parents on student learning outcomes in mathematics learning assessment courses during the covid-19 period. The type of research used is quantitative research with a descriptive approach. The sample in this study amounted to 30 students and their parents. Data collection techniques using questionnaires and observation sheets. The analysis technique used is multiple linear regression analysis. Before testing the hypothesis, a prerequisite test was conducted, namely the normality test and the multicollinearity test. The results showed that (1) the use of gadgets had a partial and significant effect on student learning outcomes with sig. $0.00<0.05$ and thit value $6.644>$ ttable 2.048, (2) the role of parents partially and significantly influences student learning outcomes with sig. $0.040<0.05$ and thit value $2.153>$ ttable 2.048 , (3) the use of gadgets and the role of parents simultaneously have a positive effect on student learning outcomes with Fhit value 28.159 greater than F table 3.35. based on the results of the study, it can be concluded that there is an influence of the use of gadgets and the role of parents on student learning outcomes.
\end{abstract}

Keywords: The Use of Gadgets, The Role of Parents, Learning Outcomes

\begin{abstract}
Abstrak
Tujuan penelitian ini adalah untuk mengetahui adanya pengaruh penggunaan gadget dan peran orang tua terhadap hasil belajar mahasiswa pada mata kuliah assesmen pembelajaran matematika di masa covid-19. Jenis penelitian yang digunakan adalah penelitian kuantitatif dengan pendekatan deskriptif. Sampel dalam penelitian ini berjumlah 30 mahasiswa dan orang tua mahasiswa. Teknik pengumpulan data menggunakan angket dan lembar observasi. Teknik analisis yang digunakan adalah analisis regresi linear berganda. Sebelum melakukan uji hipotesis, dilakukan uji prasayarat yaitu uji normalitas dan uji multikolinearitas. Hasil penelitian menunjukkan bahwa (1) penggunaan gadget berpengaruh secara parsial dan signifikan terhadap hasil belajar mahasiswa dengan nilai sig. $0.00<0.05$ dan nilai thit $6.644>\mathrm{t}_{\text {tabel }} 2.048$, (2) peran orang tua berpengaruh secara parsial dan signifikan terhadap hasil belajar mahasiswa dengan nilai sig. $0.040<0.05$ dan nilai $t_{\text {hit }} 2.153>\mathrm{t}_{\text {tabel }} 2.048$, (3) penggunaan gadget dan peran orang tua secara bersama-sama berpengaruh positif secara simultan terhadap hasil belajar mahasiswa dengan nilai Fhit 28.159 lebih besar dari $\mathrm{F}_{\text {tabel }}$ 3.35. berdasarkan hasil penelitian, dapat disimpulkan bahwa ada pengaruh penggunaan gadget dan peran orang tua terhadap hasil belajar mahasiswa.
\end{abstract}

Kata kunci: Penggunaan Gadget, Peran Orang tua, Hasil Belajar

Copyright (c) 2021 Stefania Baptis seto, Maria Trisna Sero Wondo, Maria Fatima Mei

$\triangle$ Corresponding author: Stefania Baptis Seto

Email Address: stefaniseto@gmail.com (Jl. Sam Ratulangi, Ende-Flores-NTT, Indonesia)

Received 23 June 2021, Accepted 10 July 2021, Published 25 July 2021

\section{PENDAHULUAN}

Perkembangan teknologi dan informasi mengalami kemajuan yang sangat pesat, ditandai dengan kemajuan pada bidang informasi dan teknologi. Bangsa Indonesia merupakan salah satu bangsa yang ikut terlibat dalam kemajuan media informasi dan teknologi (Ameliola, S., Nugraha, 2013). Teknologi muncul dalam berbagai macam jenis, dan selalu ada pembaruan fiturnya dari hari ke hari. Salah satunya adalah alat komunikasi atau yang biasa kita kenal dengan gadget atau handphone (Widiantari N K M et al., 2016). Salah satu hal yang membedakan gadget dengan perangkat elektronik lainnya yaitu adanya unsur kebaruan artinya dari hari ke hari gadget selalu muncul dengan menyajikan teknologi terbaru yang membuat hidup 
Pengaruh Penggunaan Gadget dan Peran Orang Tua Terhadap Hasil Belajar Mahasiswa di Masa Covid-19, Stefania Baptis

manusia menjadi lebih praktis. Gagdet merupakan salah satu bentuk nyata dari berkembangnya Ilmu pengetahuan dan teknologi (Ipteks) pada zaman sekarang dan mendatang. Tentunya dengan berkembangnya Ipteks, hal ini sangat mempengaruhi pola kehidupan manusia baik dari segi pola pikir maupun perilaku. Bantuan teknologi seperti gadget dapat mempermudah kegiatan manusia agar tidak memakan waktu yang lama. Gadget dengan berbagai fitur yang disediakan membantu para penggunanya dalam melakukan aktivitas baik dalam dunia kerja ataupun dalam dunia pendidikan dan juga kebutuhan umum sehari-hari. Gadget menjadi satu kebutuhan pokok bagi setiap orang. Gadget tidak bisa dipisahkan, bahkan jika sehari saja tidak menggunakan gadget seperti ada yang kurang. Meningkatnya penggunaan gadget atau alat-alat yang dapat dengan mudah terkoneksi dengan internet ini, mengalami peningkatan dari waktu ke waktu. Saat ini kurang lebih 45 juta menggunakan internet, dimana Sembilan juta diantaranya menggunakan ponsel untuk mengakses internet. Padahal pada tahun 2001, jumlah pengguna internet di Indonesia hanya setengah juta penduduk. Jumlah ini semakin bertambah karena semakin mudah di dapat serta terjangkaunya harga dari ponsel cerdas (Sanjaya R., 2011).

Internet merupakan salah satu hal yang selalu dimanfaatkan dalam gadget. internet merupakan satu keajaiban penemuan di dunia. Penemuan internet merubah dunia menjadi lebih dinamis dan serba cepat. Semua menjadi lebih mudah dengan adanya akses internet. Apa saja yang tidak kita ketahui akan segera kita temukan dengan bantuan teknologi dalam hal ini internet. Kemajuan internet telah menyentuh banyak sisi kehidupan manusia. Kejadian di belahan dunia lain bisa kita ketahui dengan segera melalui internet. Manusia pun saling berinteraksi melalui internet.

Internet pun sudah digunakan pada lapisan masyarakat mulai dari anak usia 3 tahun sudah bisa mengakses fitur-fitur yang disediakan dari internet. Pada jaman sekarang ini, sebagai orang tua harus mengenalkan fungsi dan kegunaan gadget dengan fitur internet secara lebih dini terhadap anak. Sehingga pada saat ini anak tidak merasa ketinggalan zaman. Internet menyediakan fitur-fitur yang selalu diperbaruhi dari hari-hari. Mulai dari hal yang bersifat mendidik sampai dengan hal-hal yang bersifat merugikan. Oleh karena itu, sebagai pengguna gadget yang baik harus bisa menggunakan internet sesuai dengan kebutuhan.

Dalam masa covid ini, segala bentuk proses pembelajaran dilakukan dari rumah. Para peserta didik diharapakan untuk mempunyai gadget agar proses pembelajaran bisa berlangsung. Alasan peserta didik selalu menggunakan gadget dalam aktivitasnya adalah karena gadget merupakan alat komunikasi maupun alat pencari informasi yang paling mudah, praktis dan cepat (Anggraeni \& Hendrizal, 2018). Mahasiswa merupakan peserta didik yang banyak menggunakan gadget dalam proses pembelajarannya terutama pada saat proses diskusi di dalam kelas. Gadget juga dapat mempermudah mahasiswa dalam mengerjakan tugastugas yang diberikan dosen (Rachmawati et al., 2017). Tugas dan latihan dikirim oleh mahasiswa melalui aplikasi yang sudah disediakan. Salah satu contohnya adalah google classroom. Dengan adanya google classroom, bahan ajar, tugas maupun tes dikirim melalui aplikasi tersebut.

Dengan pembelajaran daring banyak mahasiswa yang kurang memahami dengan materi yang sudah diberikan oleh dosen, sehingga mereka hanya meyelesaikan tugas yang diberikan tanpa harus memahami materi yang diberikan. Dengan adanya internet semua tugas akan segera diselesaikan dengan waktu yang 
relatif cepat.

Para orang tua terkadang merasa bahwa internet sangat membantu mereka dalam hal menyelesaikan tugas sekolah anak mereka. Namun yang disayangkan adalah mahasiswa saat ini sudah tidak mempunyai waktu untuk membaca buku atau berusaha menyelesaikan soal itu secara mandiri tanpa bantuan internet. orang tua pun merasa khawatir dengan kebiasaan anak karena keseharian mereka lebih memilih menghabiskan waktu dengan gadget dalam hal ini adalah bermain game. Para orang tua merasa resah, dan berharap pandemi covid ini segera berakhir, sehingga anak-anak mereka bisa kembali belajar di kampus. Bertemu dan bertatap muka secara langsung dengan dosen dan juga teman-teman mereka. Sehingga jika mereka kurang memahami pembelajaran, mereka bisa langsung bertanya kepada dosen ataupun temanteman mereka. Dan mereka pun tidak terlalu terpaku kepada gadget.

Mengingat pentingnya peranan orang tua dalam mendidik anak, beberapa penelitian telah membuktikan bahwa orang tua memiliki andil yang sangat besar dalam kemampuan anak dalam lingkup pendidikan diantaranya adalah penelitian yang dilakukan (Valeza, 2017) dimana penelitiannya menunjukkan peran orang tua dalam menentukan prestasi belajar siswa sangatlah besar. Selain itu penelitian yang dilakukan oleh (Kurniati et al., 2020) bahwa secara umum peran orang tua yang muncul selama pandemi covid-19 adalah sebagai pembimbing, pendidik, penjaga, pengembang dan pengawas. Peran orang tua sangat diperlukan untuk proses pembelajaran anak selama study from home, peran orang tua juga sangat diperlukan untuk memberikan edukasi kepada anak-anaknya yang masih belum bisa memahami tentang pandemi yang sedang mewabah untuk tetap berdiam diri di rumah agar tidak tertular dan menularkan wabah pandemi (Cahyati \& Kusumah, 2020). Menurut (Winingsih, 2020) terdapat empat peran orang tua selama pembelajaran jarak jauh yaitu: 1) orang tua memiliki peran sebagai guru di rumah, yang di mana orang tua dapat membimbing anaknya dalam belajar secara jarak jauh dari rumah, 2) orang tua sebagai fasilitator, yaitu orang tua sebagai sarana dan pra-sarana bagi anaknya dalam melaksanakan pembelajaran jarak jauh, 3) orang tua sebagai motivator, yaitu orang tua dapat memberikan semangat serta dukungan kepada anaknya dalam melaksanakan pembelajaran, sehingga anak memiliki semangat untuk belajar, 4) orang tua sebagai pengaruh atau director.

Kehadiran gadget dapat memberikan pengaruh positif maupun negatif bagi mahasiswa. Penggunaan gadget akan memebrikan pengaruh yang positifjika mahasiswa mampu menempatkan dengan baik penggunaan gadget tersebut, misalnya digunakan untuk mencari tahu informasi terbaru. Kemudian gadget bisa dimanfaatkan untuk menambah ilmu pengetahuan yang nantinya akan sangat berguna dalam proses diskusi di dalam kelas serta dapat membantu mahasiswa dalam mengerjakan tugas yang diberikan dosen (Rachmawati et al., 2017). Dampak positif dari pengembangan teknologi informasi dalam bidang pendidikan yaitu informasi yang dibutuhkan akan semakin cepat dan mudah diakses untuk kepentingan pendidikan (Sundusiyah, 2012).

Penggunaan gadget juga dapat memberikan pengaruh yang negatif jika mahasiswa tidak mampu menempatkan dengan baik penggunaan gadget tersebut, misalnya banyak mahasiswa yang menggunakan gadget detengah-tengah proses pembelajaran untuk menghilangkan rasa bosannya dengan membuka sosial 
Pengaruh Penggunaan Gadget dan Peran Orang Tua Terhadap Hasil Belajar Mahasiswa di Masa Covid-19, Stefania Baptis

media yang tidak berkaitan dengan materi yang sedang dibahas dalam perkuliahan. Hal tersebut dapat menyebabkan materi yang sedang dibahas atau sedang dijelaskan dosen tidak dapat diterima dengan baik oleh mahasiswa (Rachmawati et al., 2017).

Peranan Gadget dalam mata kuliah assesmen pembelajaran matematika yaitu untuk mencari materi tambahan yang berkaitan dengan mata kuliah ini. Materi tambahan yang mahasiswa butuhkan dapat diperoleh melalui artikel, blog dan jurnal-jurnal online yang terdapat di internet dengan menggunakan gadget. Hal ini dilakukan karena mengingat materi yang terdapat dalam buku hanya terbatas pada teori saja. Jika seorang mahasiswa mampu memecahkan masalah yang ada dan bisa ikut aktif dalam diskusi karena adanya bantuan gadget pastinya hal tersebut akan meningkatkan hasil belajar mahasiswa dan secara otomatis nilai IPK juga akan meningkat. Hal ini didukung oleh penelitian yang dilakukan oleh (Manumpil et al., 2015) yang menunjukkan bahwa ada hubungan penggunaan gadget dengan tingkat prestasi belajar siswa di SMA Negeri 9 Manado. Selain itu juga penelitian yang dilakukan oleh (Fatmawati, 2009) yang menyatakan bahwa terdapat pengaruh media internet terhadap hasil belajar biologi siswa SMP AL-Azhar Palu tahun pelajaran 2008/2009.

Menurut (Sudjana N, 2009) hasil belajar siswa adalah perubahan tingkah laku sebagai hasil belajar dalam pengertian yang lebih luas mencakup bidang kognitif, afektif, dan psikomotorik. Selain itu menurut pendapat (Dimyati; Mudijiono, 2006) menyebutkan hasil belajar merupakan hasil dari sutu interaksi tindak belajar dan tindak mengajar. Dari sisi guru, tindak mengajar diakhiri dengan proses evaluasi hasil belajar. Dari sisi siswa, hasil belajar merupakan berakhirnya pengajaran dari puncak proses belajar.

Berdasarkan pegertian hasil belajar di atas dapat disimpulkan bahwa hasil belajar adalah suatu perubahan yang terjadi pada siswa yang merupakan akibat dari kegiatan belajar yang dilakukannya. Perubahan yang terjadi adalah perubahan dari segi perilaku siswa dan dari segi ilmu pengetahuan. Hasil belajar yang diperoleh dari hasil belajar tidak terlepas dari faktor-faktor yang dapat mempengaruhinya antara lain: 1) faktor internal meliputi faktor jasmaniah dan faktor psikologis, 2) faktor eksternal meliputi faktor keluarga, faktor sekolah dan faktor masyarakat (Sugihartono, dkk 2007).

Berdasarkan uraian tersebut diatas maka peneliti tertarik untuk melakukan penelitian dengan judul "Pengaruh Penggunaan Gadget dan Peran orang tua terhadap Hasil Belajar Mahasiswa Di Masa Covid-19".

\section{METODE}

Jenis penelitian ini adalah penelitian deskriptif kuantitatif. Penelitian ini dilakasanakn di Program Studi Pendidikan Matematika, Fakultas Keguruan dan Ilmu Pendidikan, Universitas Flores, pada mahasiswa semester IV, pada bulan April sampai bulan Mei tahun 2021.

Populasi pada penelitian ini adalah seluruh mahasiswa semester IV pendidikan matematika yang memiliki gadget berjumlah 40 orang. Untuk pengambilan sampel penelitian dilakukan dengan teknik purposive sampling, dengan pertimbangan penentuan sampel yang digunakan dalam penelitian ini adalah kelompok mahasiswa yang memiliki gadget kemudian pertimbangan yang kedua adalah kelompok mahasiswa yang telah mengikuti mata kuliah assesemen pembelajaran matematika. Sampel dalam 
penelitian ini mahasiswa berjumlah 30 orang dan orang tua mahasiswa.

Teknik pengumpulan data yang digunakan adalah dengan penyebaran angket. Instrumen yang digunakan dalam penelitian ini adalah angket penggunaan gadget yang diberikan kepada mahasiswa dan angket peran orang tua dalam pendampingan anak saat menggunakan gadget dalam pembelajaran daring. Data hasil penelitian dianalisis menggunakan teknik analisis regresi linear berganda. Sebelum dilakukan uji hipotesis, terlebih dahulu dilakukan uji prasyarat yaitu uji normalitas dan uji multikolinearitas. Desain penelitian dapat dilihat pada gambar berikut.

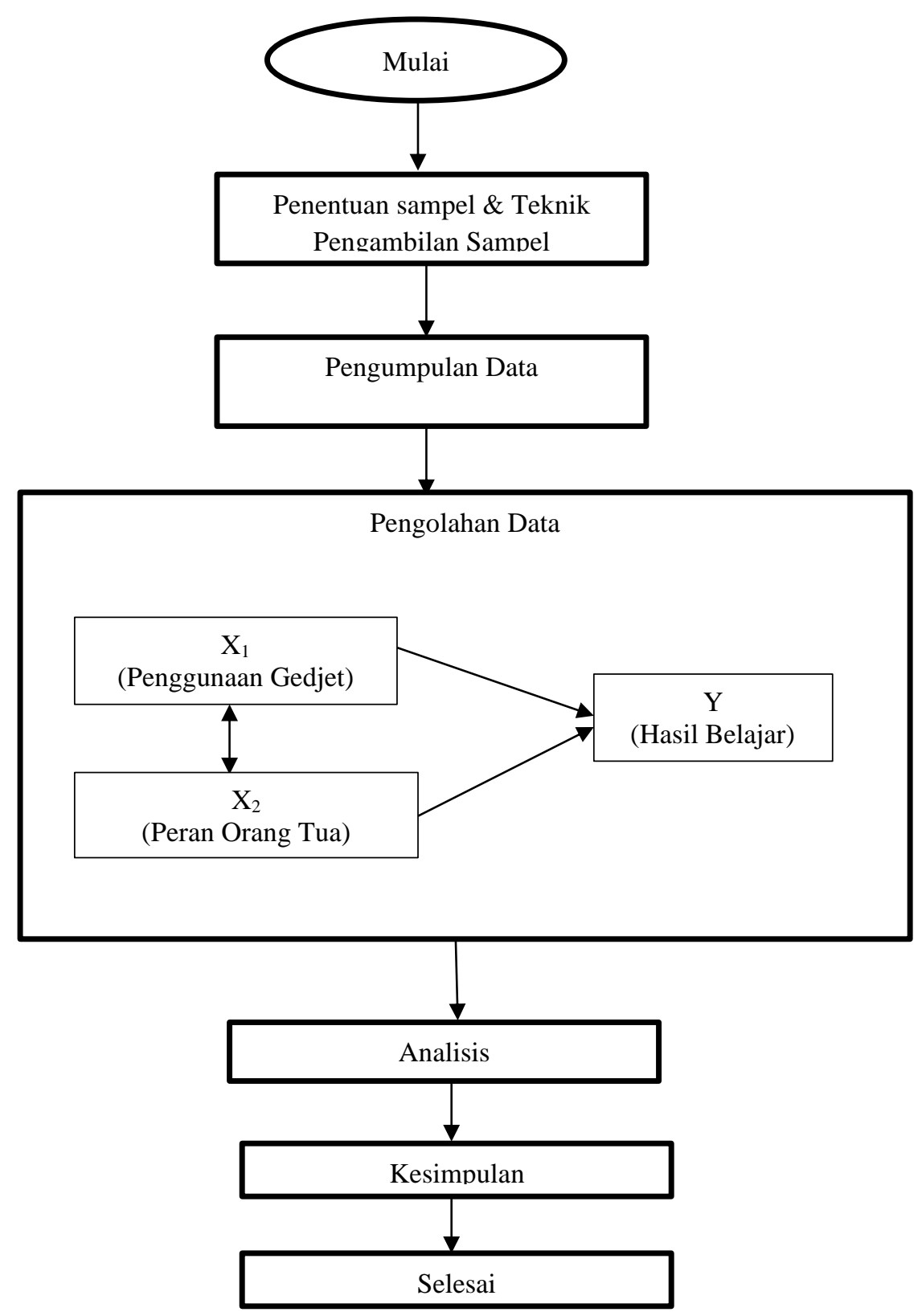

Gambar 1. Desain Penelitian

\section{HASIL DAN DISKUSI}

Berdasarkan hasil instrumen angket penggunaan gadget $\left(\mathrm{X}_{1}\right)$, peran orang tua $\left(\mathrm{X}_{2}\right)$ terhadap hasil 
belajar mahasiswa semester IV di peroleh data sebagai berikut.

Tabel 1. Data variabel X1, X2 dan Y

\begin{tabular}{|c|c|c|c|}
\hline Data & $\mathbf{X}_{\mathbf{1}}$ & $\mathbf{X}_{\mathbf{2}}$ & $\mathbf{Y}$ \\
\hline $\mathrm{N}$ & 30 & 30 & 30 \\
\hline Skor Terbesar & 87 & 119 & 86 \\
\hline Skor Terkecil & 41 & 44 & 46 \\
\hline Median & 68.00 & 77.00 & 71.00 \\
\hline Modus & 68 & 55 & 75 \\
\hline Rerata & 64.13 & 77.73 & 69.23 \\
\hline Simpangan Baku & 11.461 & 17.176 & 10.234 \\
\hline
\end{tabular}

Berdasarkan tabel 1 di atas, diketahui bahwa data variabel $\mathrm{x}_{1}$ dan $\mathrm{x}_{2}$ berbeda. Rerata variabel $\mathrm{x}_{1}$ dan $\mathrm{x}_{2}$ juga berbeda dengan beda sebesar 13,6\%. Berdasarkan nilai simpangan baku, variabel $\mathrm{x}_{1}<\mathrm{x}_{2}$. Hasil

\section{Pengujian Hipotesis}

Uji Asumsi

1. Uji Normalitas

Tabel 2. Uji Normalitas

\begin{tabular}{|c|c|c|c|c|}
\hline & & $\begin{array}{c}\text { Penggunaan } \\
\text { Gadget }\end{array}$ & $\begin{array}{c}\text { Peran } \\
\text { orang tua }\end{array}$ & Hasil Belajar \\
\hline \multicolumn{2}{|l|}{$\mathrm{N}$} & 30 & 30 & 30 \\
\hline \multirow[t]{2}{*}{ Normal Parameters $^{\mathrm{a}}$} & Mean & 64.13 & 77.73 & 69.23 \\
\hline & Std. Deviation & 11.461 & 17.176 & 10.234 \\
\hline \multirow{3}{*}{$\begin{array}{l}\text { Most Extreme } \\
\text { Differences }\end{array}$} & Absolute & .165 & .114 & .180 \\
\hline & Positive & .104 & .114 & .087 \\
\hline & Negative & -.165 & -.060 & -.180 \\
\hline \multicolumn{2}{|c|}{ Kolmogorov-Smirnov Z } & .906 & .625 & .988 \\
\hline \multicolumn{2}{|c|}{ Asymp. Sig. (2-tailed) } & .384 & .829 & .284 \\
\hline
\end{tabular}

Berdasarkan tabel 2 di atas, diketahui nilai signifikansi untuk variabel penggunaan gadget sebesar 0.384 lebih besar dari 0.05 , nilai signifikansi untuk variabel peran orang tua sebesar 0.829 lebih besar dari 0.05, dan nilai signifikansi untuk variabel penggunaan hasil belajar sebesar 0.284 lebih besar dari 0.005 , dapat disimpulkan bahwa data berdistribusi normal. Dengan demikian, asumsi atau persyaratan normalitas dalam model regresi sudah terpenuhi.

2. Uji Multikolinearitas

Berikut adalah hasil uji multikolonearitas pada Tabel 3. 
Tabel 3. Uji Multikolinearitas

\begin{tabular}{|c|c|c|c|c|c|c|c|c|}
\hline & \multirow[t]{2}{*}{ Model } & \multicolumn{2}{|c|}{$\begin{array}{l}\text { Unstandardized } \\
\text { Coefficients }\end{array}$} & \multirow{2}{*}{$\begin{array}{c}\text { Standardize } \\
\begin{array}{c}\text { d } \\
\text { Coefficients }\end{array} \\
\text { Beta }\end{array}$} & \multirow[t]{2}{*}{$\mathbf{t}$} & \multirow[t]{2}{*}{ Sig. } & \multicolumn{2}{|c|}{$\begin{array}{c}\text { Collinearity } \\
\text { Statistics }\end{array}$} \\
\hline & & B & Std. Error & & & & Tolerance & VIF \\
\hline \multirow[t]{3}{*}{1} & (Constant) & 15.635 & 7.493 & & 2.087 & .046 & & \\
\hline & $\begin{array}{l}\text { Penggunaan } \\
\text { Gadget }\end{array}$ & .662 & .100 & .742 & 6.644 & .000 & .963 & 1.038 \\
\hline & Peran orang tua & .143 & .067 & .240 & 2.153 & .040 & .963 & 1.038 \\
\hline
\end{tabular}

Berdasarkan tabel 3 di atas, pada bagian Collonearity Statistics diketahui nilai tolerance untuk variabel Penggunaan Gadget (X1) dan Peran orang tua (X2) adalah 0.963 lebih besar dari 0.10. sementara nilai VIF untuk variabel Penggunaan Gadget (X1) dan Peran orang tua (X2) adalah $1.038<10.00$. maka mengacu pada dasar pengambilan keputusan dalam uji multikolinearitas dapat disimpulkan bahwa tidak terjadi gejala multikolinearitas dalam model regresi.

\section{Analisis Regresi Linear Berganda}

1. Model

Tabel 4. Hasil Regresi Linier Berganda X1, X2 dan X3 terhadap Y

\begin{tabular}{|c|c|c|c|c|c|c|}
\hline \multirow{2}{*}{\multicolumn{2}{|c|}{ Model }} & \multicolumn{2}{|c|}{$\begin{array}{l}\text { Unstandardized } \\
\text { Coefficients }\end{array}$} & \multirow{2}{*}{$\begin{array}{c}\begin{array}{c}\text { Standardized } \\
\text { Coefficients }\end{array} \\
\text { Beta }\end{array}$} & \multirow[t]{2}{*}{$\mathbf{t}$} & \multirow[t]{2}{*}{ Sig. } \\
\hline & & $\mathbf{B}$ & Std. Error & & & \\
\hline \multirow[t]{3}{*}{1} & (Constant) & 15.635 & 7.493 & & 2.087 & .046 \\
\hline & Penggunaan Gadget & .662 & .100 & .742 & 6.644 & .000 \\
\hline & Peran orang tua & .143 & .067 & .240 & 2.153 & .040 \\
\hline
\end{tabular}

Berdasarkan hasil analisis regresi linear berganda seperti yang disajikan pada tabel 4 di atas, maka dapat dibentuk persamaan structural sebagai berikut:

$$
\mathrm{Y}=0.662 \mathrm{X} 1+0.143 \mathrm{X} 2+15.635+\text { error. }
$$

Pada tabel 4 di atas, diperoleh nilai signifikansi pada variabel Penggunaan Gadget (X1) sebesar $0.000<$ 0.05 sehingga dapat disimpulkan bahwa Penggunaan gadget (X1) berpengaruh terhadap hasil belajar (Y). Pada variabel Peran orang tua (X2) nilai signifikan diperoleh sebesar $0.040<0.05$ maka dapat disimpulkan bahwa Peran orang tua (X2) berpengaruh terhadap hasil belajar (Y).

2. $\quad$ Uji F

Tujuan analisis ini (nilai statistik F) adalah untuk melihat apakah semua variabel independen pada persamaan ini memiliki pengaruh pada variabel dependen. Jika $F_{\text {hitung }}>F_{\text {tabel }}$ atau nilai signifikan $<0.05$ maka $\mathrm{H}_{0}$ ditolak. Hasil uji $\mathrm{F}$ dengan menggunakan alat bantu computer dengan program IBM SPSS 20.0 ditunjukkan pada Tabel 5 berikut. 
Pengaruh Penggunaan Gadget dan Peran Orang Tua Terhadap Hasil Belajar Mahasiswa di Masa Covid-19, Stefania Baptis Seto, Maria Trisna Sero Wondo, Maria Fatima Mei

Tabel 5. Hasil Uji F $\mathrm{X}_{1}$ dan $\mathrm{X}_{2}$ terhadap $\mathrm{Y}$

\begin{tabular}{|l|c|c|c|c|c|c|}
\hline \multicolumn{2}{|c|}{ Model } & $\begin{array}{c}\text { Sum of } \\
\text { Squares }\end{array}$ & df & Mean Square & F & Sig. \\
\hline \multirow{2}{*}{1} & Regression & 2053.073 & 2 & 1026.537 & 28.159 & $.000^{\mathrm{a}}$ \\
\cline { 2 - 7 } & Residual & 984.293 & 27 & 36.455 & & \\
\cline { 2 - 6 } & Total & 3037.367 & 29 & & & \\
\hline
\end{tabular}

Berdasarkan pengujian Tabel 5 di atas, diperoleh nilai $\mathrm{F}_{\text {hitung }}=28.159$ dengan signifikansi uji $\mathrm{F}$ sebesar 0,000. Karena nilai Fhitung $28.159>\mathrm{F}_{\text {tabel }} 3.35$ dan sig $=0.000<0.05$ maka disimpulkan bahwa terdapat pengaruh secara simultan variabel Penggunaan Gadget $\left(\mathrm{X}_{1}\right)$ dan Peran orang tua $\left(\mathrm{X}_{2}\right)$ dalam Pendampingan Pembelajaran Daring di Masa Covid terhadap Hasil Belajar Mata Kuliah Asesmen Pembelajaran Matematika (Y).

3. Uji t

Tujuan analisis ini (uji t) adalah untuk menguji pengaruh dari masing-masing variabel bebas secara parsial atau untuk mengetahui variabel mana yang lebih mempengaruhi Hasil Belajar Mata Kuliah Asesmen Pembelajaran Matematika. Dengan kaidah sebagai berikut:

a. Dalam hal ini tingkat signifikan yang dipilih adalah 0.05 dengan kriteria jika $t_{\text {hitung }}>t_{\text {tabel }}$ maka $H_{a}$ diterima $\mathrm{H}_{0}$ ditolak

b. Jika $t_{\text {hitung }}<\mathrm{t}_{\text {tabel }}$ pada tingkat kepercayaan $95 \%(\alpha=0.05)$, maka $\mathrm{H}_{\mathrm{a}}$ ditolak dan $\mathrm{H}_{0}$ diterima. Kemudian untuk uji statistik tersebut yaitu sebagai berikut:

1) Pengujian koefisien regresi variabel Penggunaan Gadget (X1)

$\mathrm{H}_{\mathrm{a} 1}$ : Penggunaan Gadget $\left(\mathrm{X}_{1}\right)$ berpengaruh secara parsial terhadap variabel Hasil Belajar Mata Kuliah Asesmen Pembelajaran Matematika (Y)

$\mathrm{H}_{0} 1$ Penggunaan Gadget $\left(\mathrm{X}_{1}\right)$ tidak berpengaruh secara parsial terhadap variabel Hasil Belajar Mata Kuliah Asesmen Pembelajaran Matematika (Y)

2) Pengujian koefisien regresi variabel Peran orang tua $\left(X_{2}\right)$

$\mathrm{H}_{\mathrm{a} 2}$ : Peran orang tua $\left(\mathrm{X}_{2}\right)$ berpengaruh secara parsial tehadap variabel Hasil Belajar Mata Kuliah Asesmen Pembelajaran Matematika (Y)

$\mathrm{H}_{02}$ : Peran orang tua $\left(\mathrm{X}_{2}\right)$ tidak berpengaruh secara parsial terhadap variabel Hasil Belajar Mata Kuliah Asesmen Pembelajaran Matematika (Y)

Hasil pengujian parsial atau biasa dikenal dengan uji t dilihat pada tabel 6 berikut. 
Tabel 6. Hasil Uji t X1 dan X2 terhadap Y

\begin{tabular}{|c|c|c|c|c|c|c|}
\hline \multirow{2}{*}{\multicolumn{2}{|c|}{ Model }} & \multicolumn{2}{|c|}{$\begin{array}{l}\text { Unstandardized } \\
\text { Coefficients }\end{array}$} & \multirow{2}{*}{$\begin{array}{c}\text { Standardized } \\
\text { Coefficients }\end{array}$} & \multirow[t]{2}{*}{$\mathbf{t}$} & \multirow[t]{2}{*}{ Sig. } \\
\hline & & B & Std. Error & & & \\
\hline \multirow[t]{3}{*}{1} & (Constant) & 15.635 & 7.493 & & 2.087 & .046 \\
\hline & $\begin{array}{l}\text { Penggunaan } \\
\text { Gadget }\end{array}$ & .662 & .100 & .742 & 6.644 & .000 \\
\hline & Peran orang tua & .143 & .067 & .240 & 2.153 & .040 \\
\hline
\end{tabular}

Berdasarkan tabel 6 diatas, maka dapat dirumuskan persamaan regresi sebagai berikut:

1) Pengujian pengaruh $X 1$ terhadap $Y$ diperoleh nilai signifikan sebesar $0.000<0.05(\alpha=5 \%)$ dan $\mathrm{t}_{\text {hitung }} 6.644>\mathrm{t}_{\text {tabel }} 2.048$ sehingga $\mathrm{H}_{01}$ ditolak dan $\mathrm{H}_{\mathrm{a} 1}$ diterima. Jadi kesimpulannya bahwa Penggunaan gadget $\left(\mathrm{X}_{1}\right)$ berpengaruh secara parsial terhadap hasil belajar mata kuliah asesmen pembelajaran matematika. Hal ini terlihat dari nilai koefisien regresinya sebesar 0.662 sehingga pengaruh tersebut signifikan.

2) Pengujian pengaruh $X_{2}$ terhadap $Y$ diperoleh nilai signifikan sebesar $0.040<0.05(\alpha=5 \%)$ dan $\mathrm{t}_{\text {hitung }} 2.153>\mathrm{t}_{\text {tabel }} 2.048$ sehingga $\mathrm{H}_{02}$ ditolak dan $\mathrm{H}_{\mathrm{a} 2}$ diterima. Jadi kesimpulannya bahwa peran orang tua $\left(\mathrm{X}_{2}\right)$ berpengaruh secara parsial terhadap hasil belajar mata kuliah asesmen pembelajaran matematika. Hal ini terlihat dari nilai koefisien regresinya sebesar 0.143 sehingga pengaruh tersebut signifikan.

\section{Koefisien Determinasi}

Tujuan analisis ini dilakukan adalah untuk melihat seberapa besar pengaruh antara $X_{1}$ dan $X_{2}$ terhadap Y dengan cara melihat pada nilai R square (koefisien determinasi). Nilai R square hasil pengujian regresi linier sederhana dapat dilihat pada tabel 7 berikut.

Tabel 7. Hasil Koefisien Determinasi X1 dan X2 terhadap Y

\begin{tabular}{|l|c|c|c|c|}
\hline Model & $\mathbf{R}$ & R Square & $\begin{array}{c}\text { Adjusted R } \\
\text { Square }\end{array}$ & $\begin{array}{c}\text { Std. Error of the } \\
\text { Estimate }\end{array}$ \\
\hline 1 & $.822^{\mathrm{a}}$ & .676 & .652 & 6.038 \\
\hline a. Predictors: (Constant), Peran orang tua, Penggunaan Gadget \\
\hline
\end{tabular}

Berdasarkan hasil pengujian pada tabel 7 di atas, diketahui bahwa nilai $\mathrm{R}$ yang diperoleh sebesar 0.822 menunjukkan bahwa Penggunaan Gadget dan Peran orang tua memiliki hubungan positif terhadap hasil belajar mata kuliah asesmen pembelajaran matematika. Nilai R square yang diperoleh sebesar 0.676 hal ini menunjukkan bahwa hasil belajar mata kuliah asesmen pembelajaran matematika (Y) dipengaruhi sebesar 67.6\% oleh variabel Penggunaan Gadget $\left(\mathrm{X}_{1}\right)$ dan Peran orang tua $\left(\mathrm{X}_{2}\right)$, sedangkan sisanya sebesar 32.4\% dipengaruhi oleh faktor lain. 
Pengaruh Penggunaan Gadget dan Peran Orang Tua Terhadap Hasil Belajar Mahasiswa di Masa Covid-19, Stefania Baptis Seto, Maria Trisna Sero Wondo, Maria Fatima Mei

\section{Pembahasan}

Pada penelitian ini, pengaruh variabel Penggunaan Gadget $\left(\mathrm{X}_{1}\right)$ secara parsial terhadap Hasil Belajar (Y) di uji melalui Uji t yang menunjukkan nilai sig. 0,000 lebih kecil dari 0,05 yang berarti bahwa ada pengaruh secara signifikan penggunaan gadget (X1) terhadap hasil belajar (Y) dan nilai $t_{\text {hitung }} 6,644>t_{\text {tabel }}$ 2,048. Jadi dapat disimpulkan bahwa penggunaan Gadget (X1) secara parsial berpengaruh parsial dan signifikan terhadap hasil belajar mata kuliah asesmen pembelajaran matematika (Y). Pengaruh Peran orang tua (X2) terhadap Hasil Belajar Mata Kuliah Asesmen Pembelajaran Matematika (Y).

Pada penelitian ini, pengaruh variabel Peran orang tua (X2) secara parsial terhadap Hasil Belajar (Y) di uji melalui Uji t yang menunjukan nilai sig. 0,040 lebih kecil dari 0,05 yang berarti bahwa ada pengaruh secara signifikan peran orang tua (X2) terhadap hasil belajar (Y) dan nilai $t_{\text {hitung }} 2,153>t_{\text {tabel }} 2,048$. Jadi dapat disimpulkan bahwa peran orang tua (X2) secara parsial berpengaruh parsial dan signifikan terhadap hasil Belajar mata kuliah asesmen pembelajaran matematika (Y). Pengaruh Penggunaan Gadget (X1) dan Peran orang tua (X2) terhadap Hasil Belajar Mata Kuliah Asesmen Pembelajaran Matematika (Y). Variabel penggunaan gadget (X1), peran orang tua (X2) secara bersama-sama berpengaruh positif secara simultan terhadap hasil belajar mata kuliah asesmen pembelajaran matematika (Y) yang telah diuji dengan uji $\mathrm{F}$ bahwa $F_{\text {hitung }}$ sebesar 28,159> $\mathrm{F}_{\text {tabel }} 3,35$.

\section{KESIMPULAN}

Berdasarkan hasil penelitian dapat disimpulkan bahwa (1) penggunaan gadget berpengaruh secara parsial dan signifikan terhadap hasil belajar mahasiswa dengan nilai sig. $0,00<0,05$ dan nilai $t_{\text {hitung }} 6,644>$ $\mathrm{t}_{\text {tabel }} 2,048$, (2) peran orang tua berpengaruh secara parsial dan signifikan terhadap hasil belajar mahasiswa dengan nilai sig. $0,040<0.05$ dan nilai $t_{\text {hitung }} 2,153>t_{\text {tabel }} 2,048$, (3) penggunaan gadget dan peran orang tua secara bersama-sama berpengaruh positif secara simultan terhadap hasil belajar mahasiswa dengan nilai $F_{\text {hit }} 28,159$ lebih besar dari $F_{\text {tabel }} 3,35$.

\section{REFERENSI}

Ameliola, S., Nugraha, D. H. (2013). Perkembangan Media Informasi dan Teknologi Terhadap Anak dalam Era Globalisasi. Malang: Universitas Brawijaya. http://icssis.files.wordpress. com/2013/09/20130229.pdf.

Anggraeni, A., \& Hendrizal. (2018). Pengaruh Penggunaan Gadget Terhadap Kehidupan Sosial Para Siswa Sma. Jurnal PPKN \& Hukum, 13(Sosial), 64-76.

Cahyati, N., \& Kusumah, R. (2020). Peran orang tua Dalam Menerapkan Pembelajaran Di Rumah Saat Pandemi Covid 19. Jurnal Golden Age, 4(01), 4-6. https://doi.org/10.29408/jga.v4i01.2203

Dimyati; Mudijiono. (2006). Belajar dan Pembelajaran. Rineka Cipta.

Fatmawati. (2009). Pengaruh Media Internet Terhadap Hasil Belajar Biologi Siswa Kelas VII SMP AlAzhar Palu. Universitas Tadulako.

Kurniati, E., Nur Alfaeni, D. K., \& Andriani, F. (2020). Analisis Peran orang tua dalam Mendampingi Anak 
di Masa Pandemi Covid-19. Jurnal Obsesi: Jurnal Pendidikan Anak Usia Dini, 5(1), 241. https://doi.org/10.31004/obsesi.v5i1.541

Manumpil, B., Ismanto, A., \& Onibala, F. (2015). Hubungan Penggunaan Gadget Dengan Tingkat Prestasi Siswa Di Sma Negeri 9 Manado. Jurnal Keperawatan UNSRAT, 3(2), 112721.

Rachmawati, P., Rede, A., \& Jamhari, M. (2017). Pengaruh Penggunaan Gadget Terhadap Hasil Belajar Mahasiswa Pendidikan Biologi Angkatan 2013 FKIP UNTAD Pada mata kuliah Desain Media Pembelajaran. E-JIP BIOL, 5(1), 35-40.

Sanjaya R., W. C. (2011). Menyiasati tren digital pada anak menggunakan teknologi informatika (E. M. Komputindo (ed.)).

Sudjana N. (2009). Penilain Hasil Proses Belajar Mengajar. Remaja Rosda Karya.

Sugihartono, . Fathiyah K R. dan H. (2007). Psikologi Pendidikan. UNY Press.

Sundusiyah, A. (2012). Perkembangan Teknologi Informasi Komunikasi. Universitas Pendidikan Indonesia.

Valeza, A. R. (2017). Peran orang tua dalam Meningkatkan Prestasi Anak di Perum Tanjung Raya Permai Kelurahan Pematang Wangi Kecamatan Tanjung Senang Bandar Lampung. UIN Raden Intan Lampung.

Widiantari N K M, P., Suarjana, I. M., \& Kusmariyatni, N. (2016). Analisis Kemampuan Berpikir Kritis Siswa Kelas Iv Dalam Pembelajaran Matematika. Journal PGSD Pendidikan Ganesha, 4(1), 1-3.

Winingsih, E. (2020). Peran orang tua Dalam Pembelajaran Jarak Jauh. https://poskita.co/2020/04/02/peran-orangtuadalampembelajaran-\%0Ajarak-jauh/ 